\title{
On the presence of Scinax pedromedinae (Henle, 1991) (Amphibia: Anura: Hylidae) in Amazonian Brazil and northern Peru \\ Sobre a presença de Scinax pedromedinae (Henle, 1991) (Amphibia: Anura: Hylidae) na Amazônia brasileira e norte do Peru
}

\author{
Marinus Steven Hoogmoed', Teresa Cristina Sauer Avila-Pires' \\ 'Museu Paraense Emílio Goeldi. Coordenação de Zoologia. Belém, Pará, Brasil
}

\begin{abstract}
We report the presence of Scinax pedromedinae in northern Peru, near the point where the borders of Peru, Brazil, and Colombia meet (660 km northeast of Pucallpa and $900 \mathrm{~km} \mathrm{~N}$ of Puerto Maldonado), and in the Estação Ecológica Mamirauá in central Amazonas State, Brazil (1,200 km NE of Pucallpa, 1,100 km NNE of Puerto Maldonado, and $600 \mathrm{~km}$ E of the northern Peruvian locality reported here). These new records suggest a continuous distribution of this species in the western Amazon Basin, in eastern Peru, western Brazil, and northern Bolivia.
\end{abstract}

Keywords: Scinax pedromedinae. Brazil. Peru. Amazonia. Distribution extension.

Resumo: Registra-se a presença de Scinax pedromedinae no norte do Peru, próximo à tríplice fronteira entre Peru, Brasil e Colômbia (660 km a nordeste de Pucallpa e 900 km a norte de Puerto Maldonado), e na Estação Ecológica Mamirauá, na região central do estado do Amazonas, Brasil (1.200 km a nordeste de Pucallpa, $1.100 \mathrm{~km}$ a nor-nordeste de Puerto Maldonado e $600 \mathrm{~km}$ a leste da localidade do norte do Peru aqui mencionada). Esses novos registros sugerem a distribuição contínua dessa espécie na parte oeste da bacia amazônica, englobando o leste do Peru, oeste do Brasil e norte da Bolívia.

Palavras-chave: Scinax pedromedinae. Brasil. Peru. Amazônia. Extensão de distribuição.

HOOGMOED, M. S. \& T. C. S. AVILA-PIRES, 2011. On the presence of Scinax pedromedinae (Henle, 1991) (Amphibia: Anura: Hylidae) in Amazonian Brazil and northern Peru. Boletim do Museu Paraense Emílio Goeldi. Ciências Naturais 6(3): 263-271.

Autor para correspondência: Marinus Steven Hoogmoed. Museu Paraense Emílio Goeldi. Coordenação de Zoologia. Av. Perimetral, 1901 - Terra Firme. Belém, PA, Brasil. CEP $66017-970$ (marinus@museu-goeldi.br).

Recebido em 14/04/2011

Aprovado em 29/09/2011

Responsabilidade editorial: Hilton Tulio Costi

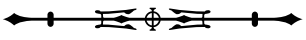




\section{INTRODUCTION}

Henle (1991) described Ololygon pedromedinae based on four specimens from Rio Tambopata (in the ZFMK collection) and 16 specimens from Cuzco Amazónico (in the collection of Kansas University), Department Madre de Dios, southern Peru. Duellman \& Wiens (1992) changed the name of the genus Ololygon to Scinax, because of priority reasons. According to the original description, the species belonged to the Ololygon [= Scinax] rostrata group as defined by Duellman (1972) and Fouquette Jr. \& Delahoussaye (1977) and which at that time contained eight species, of which S. epacrorhina (Duellman, 1972) was synonymized with Scinax garbei (Miranda-Ribeiro, 1926) by Duellman \& Wiens (1993). Lescure \& Marty (2000) described Scinax jolyi from French Guiana, thus bringing the total, including S. pedromedinae, to nine, a number mentioned by Faivovich et al. (2005) and to ten species according to Sturaro et al. (2010) (who added Scinax constrictus Lima, Bastos \& Giaretta, 2004). Faivovich (2002) concluded that the $S$. rostratus group was monophyletic, based on nine anatomical characters and one behavioural character (head down calling position). Several external characters have been used to try to identify this group, but several turned out to be variable within and between species, although the habitus of members of this group is quite distinct. In our opinion, the best external characters to recognize members of this group are the dark triangular mark between the eyes (apex pointing posteriorly) and the acuminate tip of the snout that projects well in front of the mouth and may or may not have a triangular skin flap or tubercle on top of it.

Duellman \& Wiens (1993) emended the specific name to pedromedinai, but both Henle (1997) and Dubois (2007) pointed out that this was unjustified and that the correct name should remain S. pedromedinae. Frost (2011) lists the species as $S$. pedromedinae.

Since its description, S. pedromedinae has been mentioned several times, mostly with localities in southern Peru and only recently from northern Bolivia.
Henle (1992), in his overview of the amphibians of Peru, only mentioned the type material and did not add new localities. Duellman \& Wiens (1993) gave its distribution as "confined to the upper Amazon Basin in extreme eastern Peru, where it occurs in the drainages of the Rio Purús and Rio Madre de Dios". In the map of distribution they provided a locality in Department Ucayali that is, or is near to, Pucallpa, although they did not list material from that locality in the list of specimens examined. It remains uncertain on what they based their record from the Pucallpa area. Duellman \& Wiens (1993) examined large series of several localities in the wider surroundings of Puerto Maldonado, most from Cuzco Amazonico. Duellman (1993) cited "Rio Madre de Dios drainage in southern Peru" as distribution. Duellman $(1995,2005)$ provided data on this species from Cuzco Amazonico, where it is very abundant in primary rainforest. Morales (1995), in his checklist of Peruvian amphibians, just mentioned the species but did not provide localities. Morales \& McDiarmid (1996) reported the species from Pakitza, Manu National Park, Department Madre de Dios, and mentioned it to be diurnal and nocturnal, uncommon, arboreal, and inhabiting dissected alluvial terrace forest. Duellman (1999) considered S. pedromedinae an endemic of southwestern Amazonia. Lehr (2002) only noted that the species was endemic to Peru. Angulo et al. (2004) mentioned the same distribution as given by Duellman \& Wiens (1993), adding that the species occurs at $200 \mathrm{~m}$ above sea level, and they provided a map that connects the four points given by Duellman \& Wiens (1993). This map shows a rather artificial shape defined by Peru's international borders with Brazil and Bolivia. Riva et al. (2000) and Köhler (2000) suggested that this species still might be found in Bolivia. Reichle (2007) did not mention the species for Bolivia, although it had already been reported from Nacene, Department Beni, northern Bolivia, by Moravec \& Aparicio (2004). Moravec et al. (2009) reported another specimen of $S$. 
pedromedinae from $5 \mathrm{~km}$ NE of Riberalta, Department Beni, Bolivia. Young (2007), dealing with endemic species of the eastern slopes of the Andes in Peru and Bolivia (and adjacent Amazonian lowlands), in his table mentioned S. pedromedinae from 12 localities but did not specify those localities. In a map based on just ten localities in the Department Madre de Dios, Peru (which can be accessed in Young (2007) by clicking on Scinax pedromedinae in the list of endemic species), an area of distribution of $44,897 \mathrm{~km}^{2}$ (within the Department of Madre de Dios) is predicted for S. pedromedinae. May et al. (2009) reported S. pedromedinae from all nine areas studied by them in western and southern Department Madre de Dios around Puerto Maldonado and Manu National Park. Aguilar et al. (2010) mentioned S. pedromedinae in their Table 1 and the only information they provided is that it occurs at an altitude of $200 \mathrm{~m}$. May et al. (2010) published photos of $S$. pedromedinae from the Manu and Tambopata areas in Peru. GagliardiUrrutia (2010) provided a picture of $S$. pedromedinae from the Department Loreto, but without detailed locality. Frost (2011) gave as its distribution "Upper Amazon Basin in extreme eastern Peru, in the drainages of the Río Purus and Río Madre de Dios", apparently not considering Gagliardi-Urrutia's (2010) (unspecified) Loreto, Peru, record and specimens reported by Moravec \& Aparicio (2004) and Moravec et al. (2009) from northern Bolivia.

\section{RESULTS}

During fieldwork in the border region between Brazil, Peru, and Colombia in 1989, and again during fieldwork in 1994 in the Estação Ecológica Mamirauá (now Reserva de Desenvolvimento Sustentável Mamirauá), Amazonas, Brazil, we collected a number of small hylids (see Appendix) that seemed to belong to the Scinax rostratus group, but at the time could not be identified (Figure 1). They were relatively small, flattened, had an acuminate snout, a tubercular dorsal skin, a row of tubercles on the forearm and on the lower jaw, and in general resembled Scinax nebulosus (Spix, 1824), but differed from that species by having a uniformly coloured posterior aspect of the thighs (Figures 2 and 3). Both the Mamirauá and Porto Alegria specimens have numerous round white spots on the belly in preservative.

Hoogmoed \& Avila-Pires (2001) reported the Mamirauá material as Scinax sp. Some of the specimens collected by us were directly compared with the holotype (ZFMK 39737) and the paratype ZFMK 36310 of Ololygon pedromedinae, both adult females. Böhme (2010, p. 83), in his list of ZFMK types, mentioned the holotype of Ololygon pedromedinae and categorically, but incorrectly, stated that there are "no paratypes". As Henle (1991) described the species on the basis of the holotype and 19 paratypes (three from ZFMK, 16 from Kansas University), and as the senior author examined the holotype and the paratype ZFMK 36310 in November 2009 in Leiden, Böhme (2010) clearly erred in stating that there are "no paratypes". Hopefully the ZFMK paratypes just were misplaced and are not really missing. Our material completely agreed with the type specimens examined and we now identify it as Scinax pedromedinae.

On December 5, 1989, between 10:30 a.m. and 14:30 p.m. we collected a total of ten specimens, adults (Figure 2) and juveniles, west of Porto Alegria, Rio Cayarú, Paraná Yahú, in Department Loreto, Peru, just across the border from Benjamin Constant, Brazil. This locality is $660 \mathrm{~km}$ northeast of Pucallpa and $900 \mathrm{~km} \mathrm{~N}$ of the wider Puerto Maldonado area, the two localities from where the species has been reported in Peru. It is $900 \mathrm{~km} \mathrm{NW}$ of the Bolivian localities Nacebe and Riberalta. All specimens were collected in dry 'várzea' forest, on the forest floor between leaf litter, some on the bank of a creek.

We also collected S. pedromedinae in Mamirauá (Figure 3), in 1994 between July 26 and August 3 ('cheia' = period of flooding), and between December 9 and 18 ('seca' = period with falling water levels). This locality is $1,200 \mathrm{~km}$ NE of Pucallpa, $1,100 \mathrm{~km}$ NNE of Puerto Maldonado, $600 \mathrm{~km}$ E of Rio Cayaru, the northern Peruvian 


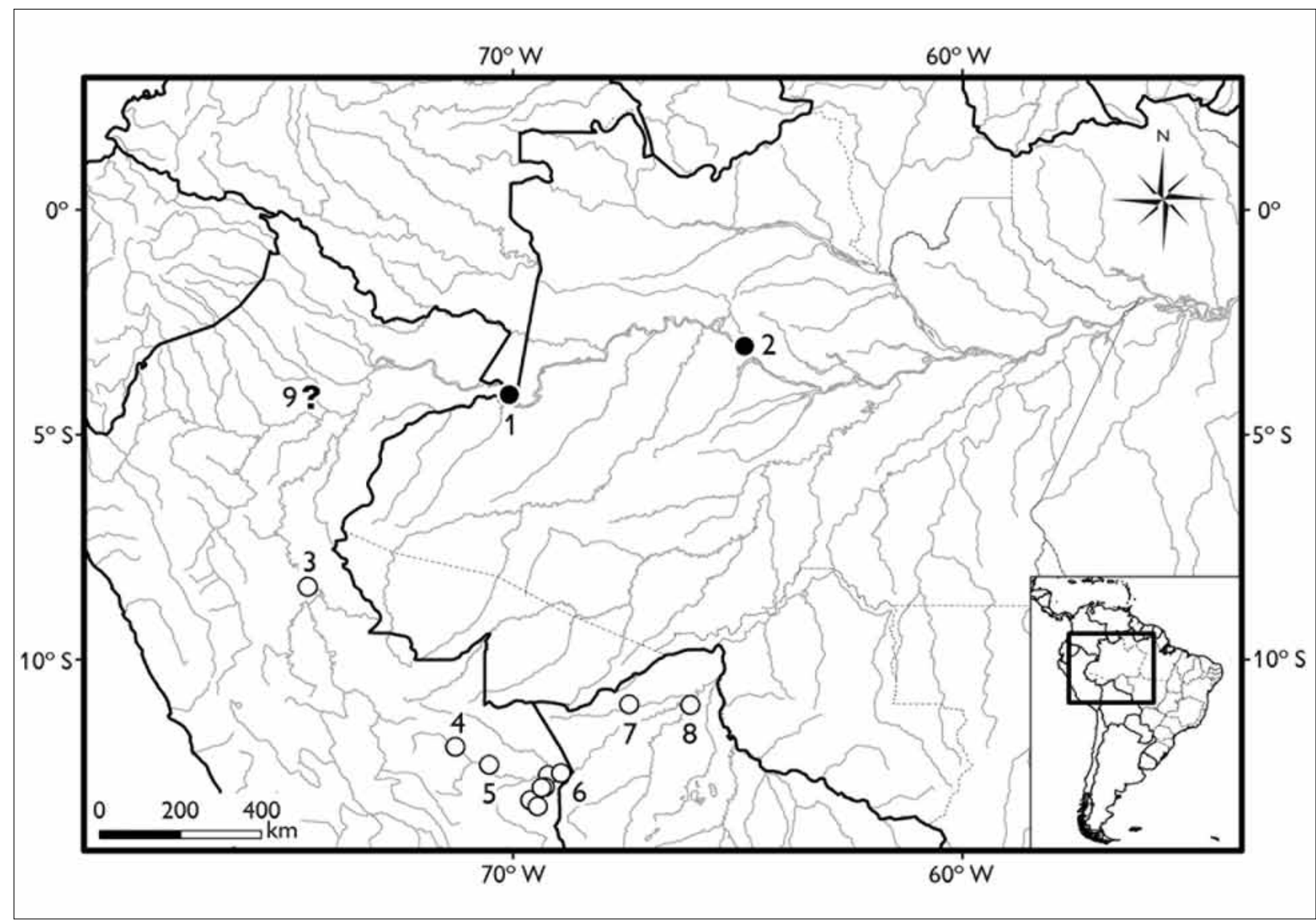

Figure 1. Map showing the known distribution of Scinax pedromedinae in Peru, Bolivia, and Brazil. New localities (dots): 1. Porto Alegria, Rio Cayaru, Loreto, Peru, 2. Estação Ecológica Mamirauá, Amazonas, Brazil. Known localities (open circles) in Peru (3-6, 9), and Bolivia (7, 8) based on literature: Peru: 3. Pucallpa area (Duellman \& Wiens, 1993); 4. Pikitza, Madre de Dios (Morales \& McDiarmid, 1996); 5. Los Amigos, Manu and Tambopata (May et al., 2009, 2010); 6. An agglomerate of localities: Tres Chimbadas, Rio Tambopata (Henle, 1991; Duellman \& Wiens, 1993); Tambopata-Candamo Reserved Zone (Rodriguez \& Emmons, 1994); Pampas del Heath region, Tambopata (Icochea-Monteza, 1994); reserva Cuzco Amazónico (Henle, 1991, Duellman \& Wiens, 1993); Eco Amazonía, Explorer's Inn, Sachavacayoc Center (Doan \& Arriaga, 2002). Bolivia, Departamento Beni: 7. Nacebe (Moravec \& Aparicio, 2004); 8. 5 km NE Riberalta (Moravec et al., 2009); Peru, Loreto: 9. (Gagliardi-Urrutia, 2010) has been indicated by a question mark, which should not be interpreted as a real locality, as this publication did not give an exact locality, but just mentioned the department.

locality reported here, and $900 \mathrm{~km} \mathrm{~N}$ of the Bolivian localities Nacebe and Riberalta. Most specimens were found in dry "restinga baixa" (Bannerman, 2001) on the forest floor among leaf litter. Only MPEG 7279 was found in flooded "restinga baixa" sitting on a dead twig $10 \mathrm{~cm}$ above the water. During the 'cheia', only half grown specimens were found, during the 'seca' only adults were found. All specimens were collected during daytime between 13:00 and 18:00 p.m.

\section{DISCUSSION}

The habitat of the Rio Cayaru and Mamirauá material (forest along waterways) agrees with that described for the type material (Henle, 1991) and other material from Peru (Duellman \& Wiens, 1993; Duellman, 1995, 2005) and Bolivia (Moravec \& Aparicio, 2004). The habitat known for this species is completely different from that of the similar $S$. nebulosus (Spix, 1824) (a closely related species [Faivovich, 2002]) which occurs in open situations (Hoogmoed, 1993),

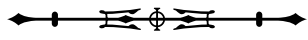




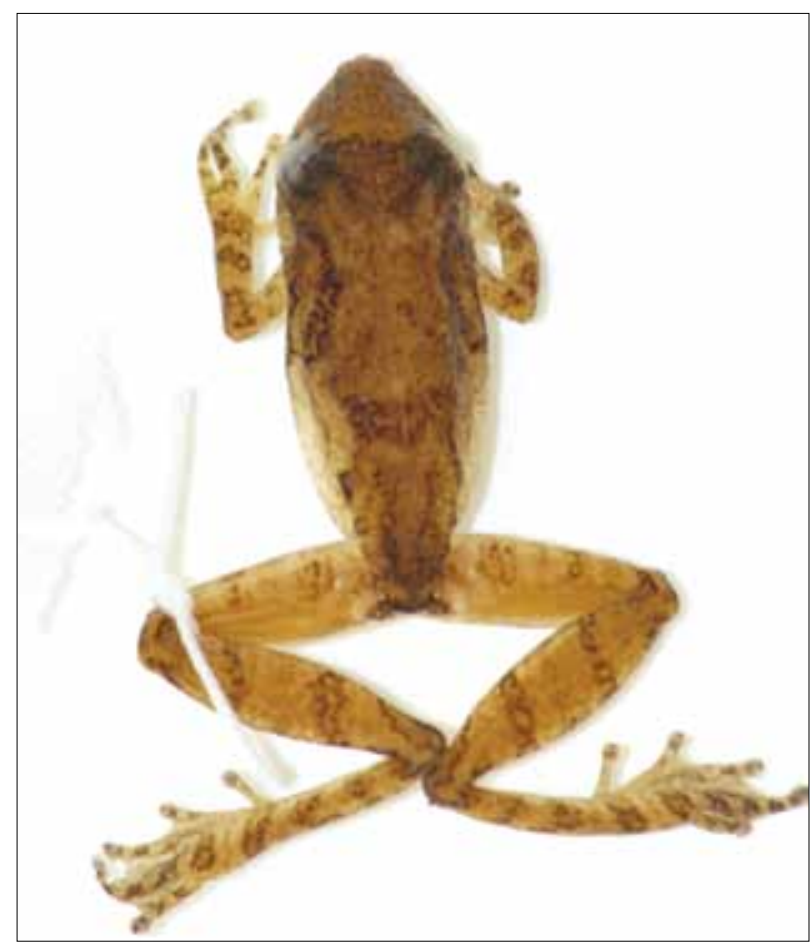

Figure 2. Scinax pedromedinae from W of Porto Alegria, Rio Cayaru, Loreto, Peru, MPEG 5343 (SVL 23.5 mm).

like savannas, floating meadows, and disturbed areas with secondary vegetation, but never in forest.

In addition to a remark made by Duellman \& Wiens (1992, p. 16) about the calling behaviour of males of the S. rostratus group, we can add that males of $S$. nebulosus in Suriname, French Guiana, and Brazil generally (but not always) also call sitting in a more or less vertical position with the head pointing down.

Another species of the $S$. rostratus group of Duellman (1972) and Duellman \& Wiens (1992) that occurs in the area between Mamirauá and Benjamin Constant is S. garbei (Miranda-Ribeiro, 1926), but this is a much larger species that has brightly (yellow or orange) patterned anterior and posterior surfaces of the thighs and can not be confused with $S$. pedromedinae.

The distinct light inguinal spot as reported by Henle (1991) is evident in most of our specimens either as an inguinal or as a flank spot, in some specimens (MPEG 7443 and 7469, RMNH 42009) it is indistinct. The northern Peruvian specimens in life had a large light to reddish brown area on the back, with dark green to black marks, the flanks were green. The back of the thighs was dark blue-green without black pattern. The ventral parts of limbs were bluish green. Belly and throat white. Bones green. The upper part of the iris was brown, the lower part silvery.

The recognition of $S$. pedromedinae, and its discovery in Mamirauá, might give rise to speculations that Hyla nebulosa Spix, 1824, described from the Rio Tefé on the southern bank of the Rio Solimões, not far from Mamirauá, actually could be the same species as the one reported here. Hoogmoed \& Gruber (1983) synonymised Hyla egleri Lutz, 1968 with H. nebulosa and designated the holotype of the first name as the neotype for Hyla nebulosa, thus changing the type locality of $H$. nebulosa (currently Scinax nebulosus) to Belém, State of Pará, Brazil. Considering the fact that Spix (1824) in his description specifically mentioned the black bars on the anterior aspect of the thighs and the blue spots on the posterior aspect, lead us to believe that Hoogmoed \& Gruber (1983) were right in synonymising $H$. nebulosa and $H$. egleri. This leads to the conclusion that either $S$. nebulosus still might be found in Tefé or surroundings (in open situations), or that the type locality mentioned by Spix (1824) was wrong (most likely in our opinion). There is a good possibility that many or all specimens referred to $S$. nebulosus from central and western Brazil and Bolivia in fact are S. pedromedinae (Hoogmoed, 1993; Riva et al., 2000, but see Moravec et al., 2009, who reported among their comparative material $S$. nebulosus from a locality only $3 \mathrm{~km}$ distant from the locality from where they report $S$. pedromedinae).

\section{CONCLUSIONS}

The present findings show that $S$. pedromedinae is not a species endemic to Peru, and do extend the range of the species considerably to the north and northeast of the Peruvian localities reported by Duellman \& Wiens (1993) 


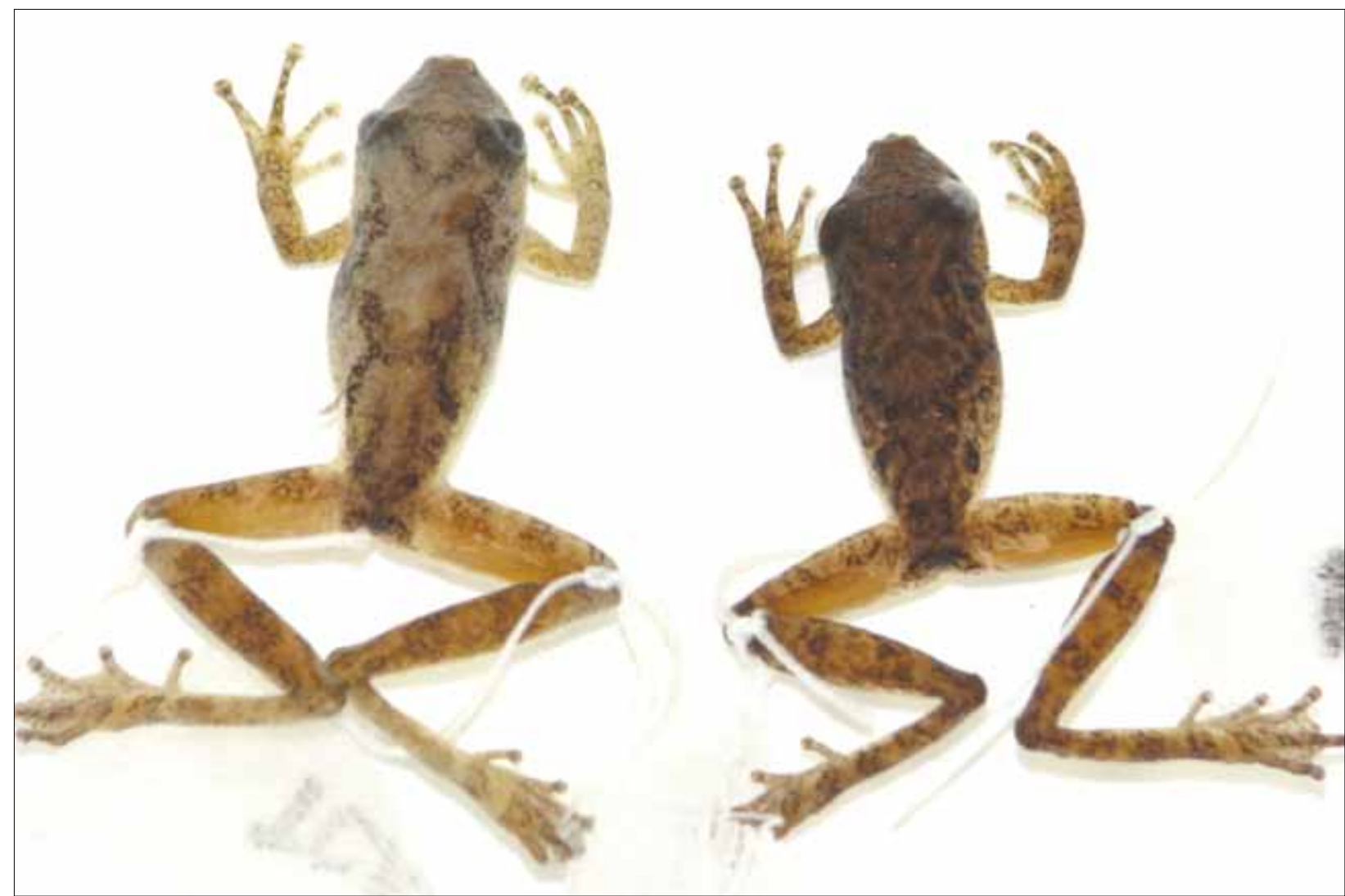

Figure 3. Specimens of Scinax pedromedinae from Mamirauá, Amazonas, Brazil: left MPEG 7443 (SVL 25.8 mm), right MPEG 7469 (SVL 23.3 mm).

and other authors. These new records and the material recently reported from northern Bolivia (Moravec \& Aparicio, 2004; Moravec et al., 2009) suggest a continuous distribution of this species in the western Amazon Basin in eastern Peru, western Brazil (and most likely also in adjacent Colombia), and northern Bolivia. This is the first time this species is reported from Brazil and northern Peru.

\section{ACKNOWLEDGEMENTS.}

We thank the Sociedade Civil Mamirauá (now Instituto de Desenvolvimento Sustentável Mamirauá) in Tefé, Amazonas, Brazil, for the invitation to perform fieldwork in Mamirauá and for providing transport and lodging during our stays in 1994. Dr. Wolfgang Böhme, Zoologisches Forschungsinstitut und Museum A. Koenig, Bonn (ZFMK), kindly permitted the senior author to examine type material under his care. Marcelo J. Sturaro (MPEG) made the distribution map and provided some pertinent recent references. Fieldwork in 1989 was financed by the Nationaal Natuurhistorisch Museum, Leiden, the Netherlands (RMNH), the Stichting Wetenschappelijk Onderzoek in de Tropen [Netherlands Foundation for Tropical Research (WOTRO, grant WR 87-218.89)], and the Van Tienhoven Stichting (= Foundation), the Netherlands, and that in 1994 also by the Sociedade Civil Mamirauá. Material was collected in Brazil under IBAMA licenses 065/89-DEVIS and 036/94-DIFAS and expedition permit EX-21/89 and Portaria MCT 178 (July 13, 1993) for field work of the senior author. Material was deposited in the collections of the Museu Paraense Emílio Goeldi, Belém, Pará, Brazil (MPEG) and in the RMNH.

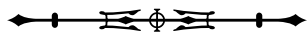




\section{REFERENCES}

AGUILAR, C., C. RAMIREZ, D. RIVERA, K. SIU-TING, J. SUAREZ \& C. TORRES, 2010. Anfíbios andinos del Peru fuera de Áreas Naturales Protegidas: amenazas y estado de conservación. Revista Peruana de Biologia 17(1): 5-28.

ANGULO, A., J. ICOCHEA \& R. REYNOLDS, 2004. Scinax pedromedinae. In: INTERNATIONAL UNION FOR CONSERVATION OF NATURE AND NATURAL RESOURCES - IUCN, 2010. IUCN Red List of Threatened Species. Version 2010.4. Available at: <www.iucnredlist.org > . Accessed on: 18 February 2011.

BANNERMAN, M., 2001. Mamirauá. A guide to the natural history of the Amazon flooded forest: 1-175. Instituto de Desenvolvimento Sustentável Mamirauá, Tefé.

BÖHME, W., 2010. A list of the herpetological type specimens in the Zoologisches Forschungsmuseum Alexander Koenig, Bonn. Bonn Zoological Bulletin 59: 79-108.

DOAN, T. M. \&W. A. ARRIAGA, 2002. Microgeographic variation in species composition of the herpetofaunal communities of Tambopata region, Peru. Biotropica 34(1): 101-117.

DUBOIS, A., 2007. Genitives of species and subspecies nomina derived from personal names should not be emended. Zootaxa 1550: 49-68.

DUELLMAN, W. E., 1972. South American frogs of the Hyla rostrata group (Amphibia, Anura, Hylidae). Zoologische Mededelingen Leiden 47: 177-192.

DUELLMAN, W. E., 1993. Amphibian species of the world: Additions and corrections. Museum of Natural History of the University of Kansas Special Publication 21: iii +372.

DUELLMAN, W. E., 1995. Temporal fluctuations in abundances of anuran amphibians in a seasonal Amazonian rainforest. Journal of Herpetology 29(1): 13-21.

DUELLMAN, W. E., 1999. Distribution patterns of amphibians in South America. In: W. E. DUELLMAN (Ed.): Patterns of distribution of amphibians. A global perspective: 255-328. Johns Hopkins University Press, Baltimore.

DUELLMAN, W. E., 2005. Cusco Amazónico. The lives of amphibians and reptiles in an Amazonian rainforest: i-xv, 1-433. Comstock Publishing Associates, Ithaca and London.

DUELLMAN, W. E. \& J. J. WIENS, 1992. The status of the hylid frog genus Ololygon and the recognition of Scinax Wagler, 1830. Occasional Papers of the Museum of Natural History, University of Kansas 151: 1-23.

DUELLMAN, W. E. \& J. J. WIENS, 1993. Hylid frogs of the genus Scinax Wagler, 1830, in Amazonian Ecuador and Peru. Occasional Papers of the Museum of Natural History, University of Kansas 153: 1-57.
FAIVOVICH, J., 2002. A cladistic analysis of Scinax (Anura: Hylidae). Cladistics 18(4): 367-393.

FAIVOVICH, J., C. F. B. HADDAD, P. C. A. GARCIA, D. R. FROST, J. A. CAMPBELL \&W. C. WHEELER, 2005. Systematic review of the frog family Hylidae, with special reference to Hylinae: a phylogenetic analysis and taxonomic revision. Bulletin of the American Museum of Natural History 294: 1-240.

FOUQUETTE, M. J., JR. \& A. J. DELAHOUSSAYE, 1977. Sperm morphology in the Hyla rubra group (Amphibia, Anura, Hylidae), and its bearing on generic status. Journal of Herpetology 11(4): 387-396.

FROST, D. R., 2011. Amphibian Species of the World: an Online Reference. Version 5.5 (31 January 2011). American Museum of Natural History, New York. Available at: <http://research.amnh. org/vz/herpetology/amphibia/> . Accessed on: 21 September 2011.

GAGLIARDI-URRUTIA, G., 2010. Anfibios y reptiles de Loreto, Peru. Rapid Color Guide 262 versión 1: pls. 1-14. Available at: <http://www.pingleton.com/field/Post/2010-photoguide_Herps_ Loreto 02.pdf $>$ Accessed on: 13 October 2011.

HENLE, K., 1991. Ololygon pedromedinae sp. nov., ein neuer Knickzehenlaubfrosch (Hylidae) aus Peru. Salamandra 27(1): 76-82.

HENLE, K., 1992. Zur Amphibienfauna Perus nebst Beschreibung eines neuen Eleutherodactylus (Leptodactylidae). Bonner zoologische Beiträge 43(1): 79-129.

HENLE, K., 1997 Scinax pedromedinai: an unjustified emendation of Ololygon pedromedinae Henle, 1991. Herpetological Review 28(2): 67.

HOOGMOED, M. S., 1993. The herpetofauna of floating meadows. In: P. E. OUBOTER (Ed.): Freshwater ecosystems of Suriname: 199-213. Kluwer Academic Publishers, Dordrecht.

HOOGMOED, M. S. \& U. GRUBER, 1983. Spix and Wagler type specimens of reptiles and amphibians in the Natural History Musea in Munich (Germany) and Leiden (The Netherlands). Spixiana Supplement 9: 319-415.

HOOGMOED, M. S. \& T. C. S. AVILA-PIRES, 2001. Amphibia. In: M. BANNERMAN: Mamirauá. A guide to the natural history of the Amazon flooded forest: 164. Instituto de Desenvolvimento Sustentável Mamirauá, Tefé.

ICOCHEA-MONTEZA, J., 1994. Amphibians and reptiles of the Pampas del Heath Region. In: R. B. FOSTER, J. L. CARR \& A. B. FORSYTH (Eds.): The Tambopata-Candamo Reserved Zone of Southeastern Perú: a biological assessment. RAP Working Papers, Conservation International 6: 71-72, 154-155.

KÖHLER, J., 2000. Amphibian diversity in Bolivia: a study with special reference to montane forest regions. Bonner zoologische Monographien 48: 1-243.

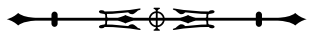


LEHR, E., 2002. Amphibien und Reptilien in Peru. Die Herpetofauna entlang des 10. Breitengrades von Peru: Arterfassung, Taxonomie, ökologische Bemerkungen und biogeographische Beziehungen: 1-208. Natur und Tier-Verlag GmbH, Münster.

LESCURE, J. \& C. MARTY, 2000. Atlas des amphibiens de Guyane. Patrimoines Naturels 45: 1-388

MAY, R. VON, K. SIU-TING, J. M. JACOBS, M. MEDINA-MÜLLER, G. GAGLIARDI, L. O. RODRÍGUEZ \& M. A. DONNELLY, 2009. Species diversity and conservation status of amphibians in Madre de Dios, southern Peru. Herpetological Conservation and Biology 4(1): 14-29.

MAY, R. VON, J. M. JACOBS, R. D. JENNINGS, A. CATENAZZI \& L. O. RODRIGUEZ, 2010. Anfibios de Los Amigos, Manu y Tambopata, Perú. Rapid Color Guide 236 version 2: pls. 1-12. Available at: <http://fm2.fieldmuseum.org/plantguides/guideimages. asp? ID = 350 > . Accessed on: 13 October 2011.

MORALES, V. R., 1995. Checklist and taxonomic bibliography of the amphibians from Peru. Smithsonian Herpetological Information Service 107: 1-20.

MORALES, V. R. \& R. W. MCDIARMID, 1996. Annotated checklist of the amphibians and reptiles of Pakitza, Manu National Park Reserve Zone, with comments on the herpetofauna of Madre de Dios, Peru. In: D. E. WILSON \& A. SANDOVAL (Eds.): Manu: The biodiversity of southeastern Peru: 503-522. Smithsonian Institution, Washington.

MORAVEC, J. \& J. APARICIO, 2004. Notes on the herpetofauna of Nacebe (Provincia Abuna, Departamento Pando, Bolivia). Časopis Národního muzea, Řada př́rodovědná (Journal National Museum, Natural History Series) 173 (1-4): 13-28.

MORAVEC, I., I. A. TUANAMA, P. E. PÉREZ \& E. LEHR, 2009. A new species of Scinax (Anura: Hylidae) from the area of lquitos, Amazonian Peru. South American Journal of Herpetology 4(1): 9-16.
REICHLE, S., 2007. Distribution, diversity and conservation status of Bolivian amphibians: 1-183 +103 p. unnumbered. Available in: <http://hss.ulb.uni-bonn.de/2007/1171/1171.pdf>. Accessed on: 21 September 2011.

RIVA, I. DE LA, J. KÖHLER, S. LÖTTERS \& S. REICHLE, 2000. Ten years of research on Bolivian amphibians: updated checklist, distribution, taxonomic problems, literature and iconography. Revista Española de Herpetologia 14: 19-164.

RODRIGUEZ, L. \& L. H. EMMONS, 1994. Amphibians and reptiles in the Tambopata-Candamo Reserved Zone. In: R. B. FOSTER, J. L. CARR \& A. B. FORSYTH (Eds.): The Tambopata-Candamo Reserved Zone of Southeastern Perú: A biological assessment. RAP Working Papers, Conservation International 6: 150-153, 184.

SPIX, J. B. VON, 1824. Animalia nova sive species novae Testudinarum et Ranarum, quas in itinere per Brasiliam annis MDCCCXVII-MDCCCXX jussu et auspicius Maximiliani Josephi I Bavariae Regis. Amphibia: 25-53, pls. I-XXII. F. S. Hübschman, Munich, Germany.

STURARO, M. J., J. F. MELO SARMENTO, A. A. LIMA, H. M. CHALKIDIKIS \& R. A. T. ROCHA, 2010. New records and distribution of the treefrog Scinax rostratus (Peters, 1863) (Amphibia: Anura: Hylidae). Herpetology Notes 3: 161-166.

YOUNG, B. E. (Ed.), 2007. Endemic species distributions on the east slopes of the Andes in Peru and Bolivia: 1-89. NatureServe, Arlington, Virginia. Available at: <http://www.natureserve.org/ aboutUs/latinamerica/maps amphibians.jsp > and <http://www. natureserve.org/aboutUs/latinamerica/maps_dist_amphibians/ Scinax_pedromedinae.jsp>. Accessed on: 21 September 2011.

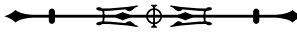




\section{APPENDIX}

\section{Material examined}

Brazil, Amazonas, Estação Ecológica Mamirauá, Cano do Teiú, S 2० 58' 10.3" W 640 54' 34.8": 1 hgr., MPEG 7279 (TCAP 2361), 30.vii.1994, leg. M. S. Hoogmoed \& T. C. S. Avila Pires.

Brazil, Amazonas, Estação Ecológica Mamirauá, Lago Araçazinho, on left bank of Paraná Apara, S $2^{\circ}$ 59' 01.1" W 640 51' 02.9": 1 ex., RMNH 45827 (MSH 6842), 3.viii.1994; 2 hgr., RMNH 42006-7 (MSH 6862), 2 hgr. MPEG 7321-22 (TCAP 2405); 1 male, RMNH 42008 (MSH 6892), 1 ex. MPEG 7443 (TCAP 2430), 9.xii.1994; all leg. M. S. Hoogmoed \& T. C. S. Avila-Pires.

Brazil, Amazonas, Estação Ecológica Mamirauá, near Lago Arati, Lago de comercialização do Barroso: 1 hgr., MPEG 7331, 26.vii.1994, leg. H. Queiroz \& M. Marmombel.
Brazil, Amazonas, Estação Ecológica Mamirauá, Boca do Mamirauá, S307' 08.0” W 64 47' 32.3”: 1 ex., MPEG 7469 (TCAP 2456), 13.xii.1994, leg. M. S. Hoogmoed \& T. C. S. Avila-Pires.

Brazil, Amazonas, Estação Ecológica Mamirauá, Lago Juruá Grande, S $3^{\circ} 01$ ' 39.1” W 64 51' 03.7”: 1 male, RMNH 42009 (MSH 6939), 18.xii.1994, leg. M. S. Hoogmoed \& T. C. S. Avila-Pires.

Peru, Departamento Loreto, W of Porto Alegria, Rio Cayaru, Paraná Yahú, S 4 06' 25" W 7004' 53": 5 ex. MPEG 5334, 5341-44, 2 ex. RMNH 45914-15 (MSH 5620), 3 ex. RMNH 45910-12 (MSH 5626), 5.xii.1989, leg. M. S. Hoogmoed \& T. C. S. Avila-Pires. 
